\title{
A Direct Test of the Homevoter Hypothesis
}

\author{
Carolyn A. Dehring ${ }^{\dagger}$, Craig A. Depken ${ }^{\dagger \dagger}$, and Michael R. Ward ${ }^{\dagger \dagger \dagger}$
}

June 2007

\begin{abstract}
We propose a methodology that facilitates a direct test of the homevoter hypothesis, which posits that homeowner/voter support for a public good project is positively related to the project's expected effect on property values. First, we estimate how events that indicate an increasing probability that the public good project will be undertaken impact local residential property values before the referendum is held. These pre-vote impacts are considered noisy signals to homeowners about the market's assessment of the net marginal benefits of the project. Second, we aggregate these market signals to the precinct level and relate them to precinct-level voting results concerning the proposed project. We apply this method to the 2004 referendum in Arlington, Texas, concerning a publicly subsidized stadium to host the NFL Dallas Cowboys. The analysis supports the homevoter hypothesis and establishes a possible methodology for future evaluations in this small but growing empirical literature.
\end{abstract}

JEL Classification Codes: L83, R53, H73

Keywords: economic impact, event studies, sports, property values, stadiums

The authors thank Tom Thibodeau and Jim Kau for helpful comments on an earlier draft of this paper. We also thank participants at the 2006 Southern Economic Association annual meetings, the 2007 Allied Social Sciences Association annual meetings, and the Andrew Young School of Policy Studies Urban, Regional and Environmental Economics Colloquium (UREEC) at Georgia State University for helpful comments.

${ }^{\dagger}$ Carolyn A. Dehring, Department of Insurance, Legal Studies and Real Estate, The University of Georgia, 706-542-3809 (office), cdehring@terry.uga.edu

${ }^{+\dagger}$ Craig A. Depken, II, Department of Economics, University of Texas at Arlington, 817272-3290 (office), 817-272-3145 (fax), depken@uta.edu

${ }^{+\dagger}$ Michael R. Ward, Department of Economics, University of Texas at Arlington, 817272-3090 (office), 817-272-3145 (fax), mikeward@uta.edu 


\section{Introduction and Motivation}

Standard voting models assume voters show more support for public spending projects when the expected marginal consumption benefits exceed the marginal costs. When the net benefits of the project influences the value of voters' asset holdings, the resulting wealth effect will be among the factors influencing voting behavior. The capitalization of local public goods into house prices has been well established in the economics literature. ${ }^{1}$ Both the models of Wildasen [2] and Sonstelie and Portney [3] reveal that voters prefer the level of a public good that maximizes the value of their house. If the public good level is not optimal from a purely consumption perspective, the voter can sell the house and move. ${ }^{2}$ Voter support of local public goods or services which preserve or enhance house values has been coined the "homevoter hypothesis" by Fischel [5].

There are just two related empirical tests of the homevoter hypothesis. Brunner, Sonstelie and Thayer [6] examine voter behavior in the State of California's 1993 school voucher initiative. The initiative would have subsidized private elementary and secondary schools, and hence would have decreased the willingness to pay for housing in quality public school districts. Brunner, Sonstelie and Thayer estimate the premium or discount associated with each of the 74 school districts in Los Angeles County. They establish a negative correlation between the premium paid for housing and support for the school choice initiative, which suggests that homeowners who felt their property values would be harmed by the school choice initiative voted against the proposal. In a follow-up paper, Brunner and Sonstelie [7] use survey data from potential voters regarding the State of California's 2000 voucher initiative. Their finding that homeowners without school children but in good public school districts were less likely to vote

\footnotetext{
${ }^{1}$ Oates [1] is the first empirical work on the capitalization of the level of public spending.

${ }^{2}$ Bruckner and Joo [4] show that with imperfect mobility, consumption effects will enter into the voter's calculus, although this is less so the earlier the voter expects to leave the community.
} 
for the initiative than if they lived in inferior school districts lends further support to the homevoter hypothesis.

This paper provides the first direct empirical test of the homevoter hypothesis in the context of a large discrete project. We examine voting in a referendum for a new publicly subsidized stadium for the NFL's Dallas Cowboys in Arlington, Texas. The public subsidization of sports stadiums is a controversial issue, and the debate over whether a subsidy is justified is often finalized at the ballot box. Stadium proponents highlight the quality of life improvements and economic activity generated by new sports venues, thereby justifying subsidies on the basis of public benefits. Carlino and Coulson [8], [9] contend that a stadium, or more specifically a franchise that plays in the stadium, can provide non-excludable public benefits such as civic pride and enjoyment from being a fan, for which residents may be willing to pay a premium. Tu [10] discusses jobs creation, increased local spending, and economic revitalization of depressed areas.

However, Coates, Humphreys and Zimbalist [11] note that referenda on stadium and arena subsidies have met with mixed results, suggesting that in some cases the majority of voters perceive the costs of publicly subsidized facilities to exceed the benefits. ${ }^{3}$ Those critical of stadium subsidies counter that public benefits of new stadiums tend to be overstated ex ante, and that stadium subsidies primarily provide wealth transfers to wealthy team owners, wealthy players, and those fans who attend events in the new venue.

In this paper, we empirically test whether differences in property values associated with the stadium proposal were also associated with differences in voters' relative support for the proposal. On November 3, 2004, the citizens of Arlington, Texas, were given the opportunity to

\footnotetext{
${ }^{3}$ For example, Major League Baseball's San Francisco Giants were denied a publicly built stadium by several Bay Area cities during the 1990s; the Giants eventually built a predominantly privately financed stadium on the waterfront in San Francisco proper.
} 
vote on a proposal to increase local sales and user taxes to contribute $\$ 325$ million to the construction of a new, retractable roof stadium for the NFL's Dallas Cowboys. ${ }^{4}$ The proposal was announced in early August of 2004 and, following the model of other successful referendum campaigns, the subsequent three month campaign for the Cowboys stadium focused on the benefits of hosting the Cowboys and the expected positive impact of a new stadium on the future development of the city. These claims were somewhat distractedly rebutted by a small group of anti-subsidy activists who argued against the stadium proposal as it was tendered to the voters. The proposal to build a stadium for the Cowboys passed by a margin of 55 to 45 percentage points

Our empirical strategy entails a two-step process. First, hedonic analysis of single-family residential property prices accommodates variations in property prices within the City of Arlington following two announcements that each increased the probability that a publicly subsidized stadium would be built in Arlington. Following the literature on local amenity effects, we employ a flexible distance specification that accommodates a non-monotonic but continuous house price surface. This specification allows for house prices to be affected differently at different distances from the proposed stadium site. The second step follows the applied public choice literature by relating precinct-level vote results to demographics and the estimated impacts of the two pre-vote announcements on local house prices. The research design allows us to test how expectations about the net benefits of a public good project, as reflected in the market prices for residential property, influence voter behavior. We do so by linking residential property values to an increasing probability that the public good project will be undertaken. If homeowners anticipate that the proposed public good project is causing a decrease (increase) in

\footnotetext{
${ }^{4}$ In December 2006, approximately one year into construction, it was announced that the stadium will cost $\$ 1$ billion. The city's contribution is ostensibly capped at $\$ 325$ million.
} 
property values, homeowners should be more likely to vote against (for) the proposal. Our empirical findings reveal that the direction and the magnitude of the house price effects explain voter behavior in a manner consistent with the homevoter hypothesis.

The paper expands on Brunner, Sonstelie and Thayer [6] in several important dimensions. First, the capitalized house price effects from an uncertain future event proxy for the wealth effect homeowners would use in determining whether to support the proposed project. Explaining voting outcomes through this wealth effect is a direct test of the homevoter hypothesis. Second, because we have two announcement effects, each of which increases the likelihood that a referendum will pass, we examine whether price effects under reduced uncertainty are more important in explaining voting outcomes. Finally, because both wealth effects and consumption effects vary with distance from the proposed stadium site, the spatial element plays prominently in the analysis.

In the next section we provide some background on the Dallas Cowboys search for a host community and the events leading up to the eventual passage of the referendum in Arlington. We then present the house price and voting analysis, respectively. These are followed by some robustness checks. The paper concludes with a discussion of issues involved with voting on large, discrete municipal projects.

\section{Background}

In April 2001, the Dallas Cowboys announced they were interested in replacing Texas Stadium, which was built in 1972. Discussions concerning several preliminary proposals were tabled after the September 11, 2001 attacks in New York City, and the Cowboys stadium search did not return to public light until late 2003. At this time, the City of Dallas proposed to replace the aging Cotton Bowl with a new retractable roof stadium, paid for with a countywide tax. This 
proposal was ultimately abandoned in spring 2004, in large part because the City of Dallas likely would have been exempt from the countywide tax increase.

On July 17, 2004, the mayor of Arlington announced that he had been in negotiations with the team about the potential of building a new stadium in Arlington. On August 17, 2004, the Arlington city council approved a ballot initiative to be decided during the November 3, 2004 general election. The ballot initiative was comprised of two parts. First, that the city would provide up to $\$ 325$ million in public dollars for land acquisition and construction costs for a new retractable roof football stadium for the Dallas Cowboys. The second allowed the city to increase the local sales tax by one half percent, increase car rental taxes by two percentage points and to increase the hotel occupancy tax by five percentage points; the proceeds from the tax increases would be used to retire the debt incurred for the city's contribution to the stadium's construction. On November 3, 2004, the voters of Arlington approved the ballot initiative 55\% to $45 \%$. The new stadium is scheduled to open for the 2009 NFL football season.

During the stadium campaign, pro-stadium activists solicited an economic impact study, and produced television, radio, mass mailings, and newspaper advertising that touted the economic impact figures generated in their study. Proponents claimed that the new stadium would increase local business revenue, create jobs, and spur redevelopment of surrounding areas. The Cowboys team was a major financial contributor to the campaign supporting the stadium subsidy. Players posted yard signs, and the famous team cheerleaders attended campaign events to encourage passage. Ultimately stadium proponents out-spent anti-subsidy activists $\$ 6$ million to $\$ 43,000$.

The Cowboys stadium referendum in 2004 was only one of many that have been held throughout the United States since 1990. The dramatic increase in the number of new stadiums 
across the four major sports in the United States has been accompanied by a large and wellestablished literature investigating the impacts of new stadiums on local economies, including a new stadium's impact on local development (Campbell [12] and Nelson [13]), local employment and income levels (Baade and Dey [14] and Coates and Humphreys [15]) local tourism and hotel occupancy rates (Lavoi and Rodriguez [16]), and local tax revenue (Coates [17], and Depken and Coates [18]). In a different vein, several papers have investigated the impact of a new stadium on attendance (for example, Clapp and Hakes [19]), team winning percentage (Quinn et al. [20]), and the financial status of the franchise that plays in the stadium (Depken [21]). The empirical results consistently show that the impact of a new stadium on local economies is dramatically less than advertised before the stadium is constructed and in some instances might actually be negative. $^{5}$

The literature investigating stadium referenda themselves is relatively sparse. Agostini, et al. [23] were the first to estimate a vote-share model in the context of stadium referenda, focusing on 1989 and 1996 votes concerning public subsidization of a new stadium for the San Francisco Giants baseball team. In both votes, they find several demographic variables to be correlated with greater support for the stadium, including income, education, white-collar employment, and Asian heritage. Moreover, they find that the percentage of support for the stadium proposal increased by approximately $15 \%$ when the public subsidy was dramatically reduced in the 1996 proposal, which secured majority support. In an intra-city analysis, Depken [24] investigates how fan loyalty in professional baseball influences the outcome of stadium referendum outcomes in host cities using a probit analysis. He finds that teams with relatively stronger fan bases, i.e., greater fan loyalty, have a higher probability of securing public financing for a new stadium through the referendum process, but his analysis does not include many of the

\footnotetext{
${ }^{5}$ See Siegfried and Zimbalist [22] for a review of the literature concerning the impact of sports on local economies.
} 
demographics that are common to vote-share models. Coates and Humphreys [25] are closest in spirit to the study undertaken here and were the first to empirically investigate how proximity to a proposed stadium influences support for a stadium proposal. They investigate several votes in Green Bay, Wisconsin, and Houston, Texas, concerning renovating existing or building new stadiums. Their study suggests that proximity to the proposed stadium had a significant and positive impact on the relative support for a stadium proposal.

While the existing literature focusing on the outcomes of stadium votes suggests that many elements contribute to the probability of success, one influence that has not been included is the anticipated impact of the new stadium on local residential property values, specifically, the homevoter hypothesis. To directly test this hypothesis, in the context of the Cowboys stadium search, we first estimate the impact of the proposed stadium subsidy on property values in Arlington leading up to the stadium referendum, which coincided with the general election in 2004. We then calculate the estimated dollar impact of the two pre-vote announcements on houses that sold in Arlington during the summer of 2004. We then aggregate estimated dollar impacts for properties that sold during a time period into voting precincts to infer the average impact on all houses in that precinct. We then relate the support for the stadium referendum, reflected in percentage of votes in the affirmative, to precinct level demographics, the estimated price effects, and the distance of the precinct's voting location relative to the proposed stadium site.

\section{House Price Model and Results}

Before the Cowboys stadium referendum two specific public announcements increased the probability that the stadium would be built in Arlington. We assume that homeowners observe 
signals from residential property transactions in their immediate neighborhood from which they can estimate the anticipated net effect of the proposed stadium on the market value of their house. If the market responds to the proposed public good project with an increase (decrease) in the price of residential property, everything else equal, the proposed public good can be viewed as contributing a net benefit (cost) to the local population. While homeowners do not receive direct signals about the value of their own home unless they put it on the market, they do observe transaction prices of properties in their immediate neighborhood. From these transaction prices, homeowners extract a (noisy) signal about whether the market as a whole expects the proposed project to convey net benefits.

The first stage of our empirical approach is an extension of Dehring, Depken, and Ward [26] in which five specific announcements concerning the broader search for a stadium site for the Dallas Cowboys in 2004 is investigated. Their inter-city analysis utilizes a differences-indifferences identification scheme within a hedonic pricing model to estimate the average house price effect within Arlington relative to surrounding cities. The announcement dates used in this study that pertain to Arlington are presented in Table 1. Moreover, as we include only the city of Arlington in the empirical analysis, a difference-in-difference approach is not necessary.

The hedonic model of stadium amenity effects developed here features a piecewise linear distance function. This specification accommodates a non-monotonic but continuous house price surface as a function of the distance from the proposed stadium site. Since our dependent variable is the logarithm of price, we implicitly assume that the amenity effect is proportional to the house value otherwise. The model is: 


$$
\operatorname{Ln}\left(\text { PRICE }_{i}\right)=\Gamma C H A R+\left[\begin{array}{l}
\left(\beta_{0}+\sum_{j=1}^{3} \beta_{j}\right)(12-D S T A D) A N N_{j} \\
+\left(\beta_{3}+\sum_{j=1}^{3} \beta_{j+3}\right)(3-D S T A D) D_{3} A N N_{j} \\
+\left(\beta_{6}+\sum_{j=1}^{3} \beta_{j+6}\right)(2-D S T A D) D_{2} A N N_{j} \\
+\left(\beta_{9}+\sum_{j=1}^{3} \beta_{j+9}\right)(1-D S T A D) D_{1} A N N_{j}
\end{array}\right]+v_{i},
$$

where CHAR is a vector of housing characteristics and $\Gamma$ is a vector of parameter values. Housing characteristic include lot size in acres, square feet of living space, number of baths, age of house in years, number of parking spaces, number of stories, and whether there is a pool on the property. The model also includes variables indicating whether the house is owner occupied, or was vacant at the time of sale, respectively. The percent of elementary students rated acceptable and commendable on the Texas Assessment of Knowledge and Skills (TAKS) test, respectively, at the public elementary school associated with the property are included in the model. These two variables are used to control for the quality of the elementary school to which any appropriately-aged children living in the house could attend. ${ }^{6}$ The model also includes a set of dummy variables which indicate the month in which the sale was negotiated assuming 30 days from date of negotiation to closing.

Our distance specification identifies price effects attributable to the proposed stadium. Moreover, the flexible functional form allows the percentage change in price per mile to differ near the proposed stadium site and across announcements. The variable DSTAD is the greatcircle distance from the property to the proposed stadium site measured in miles. The maximum distance between a property in our sample and the proposed stadium site is 12 miles, therefore 12

\footnotetext{
${ }^{6}$ The analysis in Dehring, Depken and Ward [26] includes more home sales over a greater area which allowed for fixed effects for elementary schools to control for school quality.
} 
- DSTAD is the distance from the housing unit to the periphery of a circle having a 12 mile radius and the stadium as its mid-point. Thus $\beta_{0}$ indicates the percentage change in price from being an addition mile closer to the stadium during the pre-referendum announcements; $\beta_{0}$ reveals the effect of additional proximity to the stadium, rather than distance from the stadium. Likewise, $\beta_{1}$ and $\beta_{2}$ measure the marginal effect of additional proximity after the first and second announcements. A positive coefficient suggests that properties closer to the stadium carry a premium relative to properties with similar characteristics further from the stadium. Ostensibly the premium indicates that the benefits of being near the stadium, including but not necessarily limited to proximity to the events in the stadium, proximity to any expected development around the stadium, and potential revenues from parking and other concessions, dominate the costs of being near the stadium, including but not limited to crowding, noise, or additional crime. A negative parameter coefficient would suggest the costs of being nearer the stadium outweigh the benefits of being nearer the stadium.

Following $\mathrm{Tu}$ [10] we allow for different effects associated with distance for the first three miles from the stadium. ${ }^{7}$ The variables $D_{1}, D_{2}$, and $D_{3}$ indicate whether the property is within 1, 2, or 3 miles of the proposed stadium site, respectively. The piecewise linear distance function is therefore kinked at 1,2 and 3 miles from the stadium site. The coefficients $\beta_{3}, \beta_{6}$, and $\beta_{9}$ reflect the additional percentage change per mile from being within 3,2 and 1 mile of the stadium during the pre-referendum announcements, respectively. Together these coefficients reveal whether the stadium is placed in a local value "crater" or value "peak" on the larger Arlington price surface.

\footnotetext{
${ }^{7}$ While we test for price effects beyond 3 miles, none of these are significant, consistent with Tu.
} 
The price effects of interest concern the stadium announcements. The announcement variables, $A N N_{\mathrm{j}}, \mathrm{j}=1,2,3$ correspond to Announcement 1, 2 and 3 listed in Table $1 .^{8}$ These variables indicate whether the property sale was negotiated following the relevant stadium announcement, assuming 30 days to closing. Thus, the remaining coefficients in the model reveal whether an announcement contributed any additional percentage change in price per unit of distance within a given distance from the proposed stadium site. Any citywide price effects from stadium announcements 1,2 or 3 would be indicated by the significance of $\beta_{1}, \beta_{2}$, or $\beta_{3}$, respectively. ${ }^{9}$ The remaining 9 coefficients reveal the additional percentage change in price per mile closer to the stadium within 1, 2, or 3 miles from the stadium, respectively, following announcement 1,2 , or 3 , respectively.

The data for the hedonic price model, which include sale price, date of sale, and housing characteristics, were obtained from the Dallas-Fort Worth Multiple Listing Service. Elementary school TAKS (Texas Assessment of Knowledge Skills) results are obtained from the Texas Education Agency, and distance variables are generated by geo-coding each residential property's address to latitude-longitude coordinates and calculating the great circle distance from the property to various points of interest. The original sample size of properties sold in Arlington was 4,147 for the 2004 calendar year. However, missing and obviously incorrect values (e.g., 'year built' being coded as 1800 , long before the city of Arlington existed), reduces the working sample to approximately 4,000 observations. Approximately 700 properties cannot be accurately matched with information about schools' TAKS scores. Finally, MLS data was merged with

\footnotetext{
${ }^{8}$ While we allow for prices to differ before and after the actual vote, only changes related to the first two announcements are relevant to the subsequent voting analysis.

${ }^{9}$ The additional percentage change in price per mile of distance closer to the stadium for a property within 1 mile of the stadium following announcement 1 is $\beta_{1}+\beta_{4}+\beta_{7}+\beta_{10}$. The total percentage change in price per mile of distance closer to the stadium for a property within 1 mile of the stadium following announcement 1 is $\beta_{0}+\beta_{1}+\beta_{3}$ $+\beta_{4}+\beta_{6}+\beta_{7}+\beta_{9}+\beta_{10}$.
} 
parcel data from the Tarrant County Assessor's Office so that condominium sales are eliminated from the sample. Information on lot size was also obtained from this County data. Ultimately, the sample employed in this stage of the analysis is comprised of 2,241 single family detached houses that sold between January 1, 2004 and December 31, 2004. The sample characteristics are reported in Table 2.

To estimate the hedonic pricing model we apply a logarithmic transformation to the sale price. Regression results are presented in Table 3. The parameter estimates on property characteristics are as expected. ${ }^{10}$ Turning to the results relating to distance from the proposed stadium site, before the initial announcement there was a small premium related to proximity to the stadium beyond 2 miles of the proposed stadium site. In the neighborhood around the proposed stadium site, however, the results suggest that the proposed location was in the center of a value crater on the broader price surface of Arlington. The results reveal an additional percentage decrease of $9 \%$ per mile closer to the stadium within 2 miles of the stadium, and another additional decline of $14 \%$ per mile closer to the stadium within one mile of the stadium. This confirms our expectations that the proposed stadium site was in a local value depression. ${ }^{11}$

House price effects from announcements 2 and 3 are significant within 3 miles of the proposed stadium site, but not beyond 3 miles. These are graphically depicted in Figure 1. Following announcement 2 , house prices decrease by $8.5 \%$ per mile with each mile closer to the stadium for houses within three miles of the stadium. Following the stadium vote, denoted Announcement 3, this price effect effectively reverses between 1 and 3 miles from the stadium.

\footnotetext{
${ }^{10}$ House prices decrease with each additional year of age. Each additional square foot of living space contributes $0.03 \%$ to house price. Having a pool increases house price by $10 \%$, while, each additional bath adds $6 \%$. A parking space contributes $3 \%$ to price, while each additional story reduces price by $6 \%$ (controlling for house size). House prices are $0.66 \%$ higher with each additional percent of elementary students rated commendable on the TAKS test in the property's elementary school district. Finally, the lot area elasticity of value is 0.16 , suggesting that prices increase with acreage but at a decreasing rate.

${ }^{11}$ We ignore the coefficients on the distance variables that are not significant for the purposes of this discussion.
} 
However, with within 1 mile of the stadium, house prices again decrease with proximity to the stadium. Specifically, following announcement 3, there is an additional decrease in house prices of $42 \%$ per mile with each mile closer to the stadium for houses within one mile of the stadium. The cumulative loss in value for properties on the edge of the stadium is $15.4 \%$ before the vote, and $37 \%$ over the sample period. Overall, the results of the house price analysis reveal no access related net benefits from the stadium for the majority of property owners in the city of Arlington, but substantial costs to those in close proximity to the stadium. ${ }^{12}$

\section{Vote Model and Results}

In the second phase of the empirical analysis, we investigate whether the perceived costs and benefits of the referendum, as capitalized into house prices, affected voting behavior on the referendum. Specifically, we relate the percentage of 'YES' votes in a particular voting precinct to demographic characteristics of the population in that precinct and the average estimated effect of the various announcements concerning the stadium proposal on house prices in that precinct. Of particular interest is whether the average effects on housing prices in a precinct can explain variation in voting outcomes. The homevoter hypothesis predicts a direct relationship between price effects attributable to the proposed public good project and support for the projects at the voting booth, i.e., homevoters will offer more support for public good projects that provide a greater net increase the value of their property.

\footnotetext{
${ }^{12}$ It is important to note that the intra-city analysis does not reveal the total costs or benefits from the stadium announcement. This is because any costs or benefits borne equally by all Arlington residents are not testable in this framework. The intercity analysis of Dehring, Depken, and Ward [26] suggests that there was an average reduction in property values in Arlington of about $1.5 \%$ relative to the surrounding markets that would not bear any tax burden for the new stadium. A non-proportional sales tax effect, borne by Arlington residents and those who shop in the city of Arlington, may explain this discrepancy.
} 
We generate the estimated dollar impact of Announcements 1 and 2 on the sales price of each property in our sample using the results from the hedonic regression model discussed above. ${ }^{13}$ Variation in the impact of the announcements is identified through distance from the proposed stadium site and the interaction of distance with the various announcement periods. We derive a dollar estimate of how much the stadium proposal cost homeowners during the two announcement periods in the summer of 2004. We utilize this information in a voting model similar to that in Brunner, Sonstelie, and Thayer [6].

The estimated voting equation is

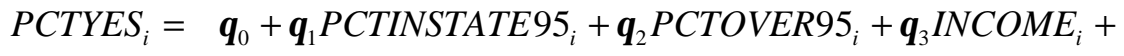

$$
\begin{aligned}
& \theta_{4} \text { UNEMPLOYED }_{i}+\theta_{5} \text { PCTWHITE }_{i}+\theta_{6} \text { DSTAD }_{i}+\theta_{7} \text { PCTOWNHOME }_{i}+ \\
& \alpha_{1} \text { DOLLARANN }_{i}+\alpha_{1} \text { NOSALESANN }_{i}+ \\
& \alpha_{1} \text { DOLLARANN }_{i}+\alpha_{1} \text { NOSALESANN }_{i}+\omega_{i} \text {, }
\end{aligned}
$$

where the dependent variable is the percentage of total votes cast in favor of the stadium proposal in precinct $i$, the $\theta$ 's and $\alpha$ 's are parameters to be estimated, and $\omega$ is a zero-mean stochastic error term.

We include the percentage of a precinct's population that was in another state in 1995 for two reasons, both of which suggest greater support for the stadium. An individual living in another state in 1995 was less likely to have participated in the 1991 referendum in Arlington to build a stadium for the Texas Rangers baseball club. Although the promised economic development around the stadium had not materialized by the time the Cowboys proposal was being considered, the memory of such promises would be strongest for those who were living in Arlington at the time of the baseball stadium referendum. Moreover, a district with a greater

\footnotetext{
${ }^{13}$ We use both significant and insignificant coefficients when calculating the estimated dollar impacts.
} 
proportion of the population in another state in 1995 might have a more transient population in general, perhaps comprised of people who might not expect to be living in Arlington for the entire life of the proposed stadium, thereby reducing their expected tax contribution to the stadium. If this is the case, we would expect to see a greater level of support for the stadium proposal. We also include the percentage of the precinct's population over the age of 65 , although the expected effect of an older population on stadium support is ambiguous. On the one hand, older residents are often on fixed incomes and are somewhat reluctant to vote for tax increases, but in this case those over 65 might have a lower expected contribution to the stadium. The net effect of these influences is not clear.

Depken [27] estimated that (league-wide) professional football is a normal good. If this is also the case in Arlington, those with greater income are expected to attend football games in greater numbers and, relative to those who do not attend games in the new stadium, stand to earn more consumer surplus from the new football stadium if the proposal were to pass. Although those with more income might bear a greater tax burden, we expect that, on net, support for the stadium will be higher in precincts with wealthier populations. Similarly areas with more unemployed individuals are less likely to anticipate large consumer surplus from a new stadium and are simultaneously more reluctant to vote for increases in potentially regressive sales taxes. Therefore the greater the unemployment we expect less support for the stadium. The impact of racial composition on stadium support is ambiguous.

The primary variables of interest in this model are the distance of the precinct from the proposed stadium site, the percentage of a precinct's population that were homeowners, and the estimated impacts of the various stadium announcements on residential property values. The further away from the proposed stadium site, the lower the net benefits of the stadium. Therefore, 
we anticipate in general that the further the voting precinct is from the proposed stadium site, the lower the support for the stadium.

The homevoter hypothesis posits that homeowners are reluctant to vote for policies that reduce their property values. In the case of the Cowboys stadium referendum, Dehring, Depken, and Ward [26] estimate that property values were falling in Arlington relative to surrounding markets. Therefore, we anticipate that precincts with a greater proportion of homeowners will have less support for the proposed Cowboys stadium, ceteris paribus.

The remaining variables measure the potential information that homeowners might have received about the influence on local property values of the various announcements concerning the stadium vote. For each property we estimate the impact of distance from the proposed stadium on actual house sales and differentiate across different announcement periods. For each precinct, we then calculate the average effect of the proposed stadium on those houses that sold during a particular announcement period; these variables are denoted DOLLARANN1 and DOLLARANN2, respectively.

Not all precincts in the city of Arlington had a house sell during a given announcement period. To accommodate this we create two dummy variables that take a value of one if there were no house sales during a given announcement period, denoted NOSALES1 and NOSALES2, respectively. For those precincts with no house sales, the dollar effects are coded as zero and the dummy variables differentiate between a price effect that equals zero and the absence of a price effect.

We anticipate that if individuals receive negative (positive) signals about the impact of the proposed stadium on properties within their precinct then support for the stadium proposal will be lower (greater), ceteris paribus. Therefore, if the behavior of Arlington voters is 
consistent with the homevoter hypothesis, we anticipate a positive coefficient on the estimated price effect. If homeowners receive no information about the impact of the stadium proposal on local property values, that is one or both of the NOSALES dummy variables takes a value of one, the impact on support for the proposal is ambiguous.

The total number of votes cast concerning the stadium proposal and the total votes in the affirmative were obtained for each of 118 voting precincts in the city of Arlington from the Tarrant County election commission. ${ }^{14}$ Election totals were available for early voting, which took place from October 1 through October 29, 2004, and voting that took place on the day of the general election, November 3, 2004. In this analysis, we combine early and day-of-election votes to generate the total number of votes from which we determine the percentage of affirmative votes in a precinct voting. We matched 113 of the 123 voting precincts in Arlington with U.S. census block data from the 2000 census, from which we obtained the population characteristics, income, unemployment, the percent white, and the percentage of residents that were home owners. Distance is calculated as the great circle distance from the proposed stadium site to the polling location of each precinct.

Descriptive statistics of the 113 voting precincts in the city of Arlington employed in our regression model are reported in Table 5. Average support for the stadium proposal throughout all of Arlington was 56.7 percent. However, there was considerable variation across precincts. Twelve precincts offered less than 50 percent support for the stadium proposal; the least amount of support (43.4 percent) was in Precinct 2451, located approximately 3 miles from the proposed stadium site. Ten percent of the average precinct's population was in another state in 1995, approximately 6.75 percent of the population was older than 65 , median household income was

\footnotetext{
${ }^{14}$ The precincts not included in our final sample include two that were technically located in Kennendale, a border city with Arlington. The remaining precincts did not report any voting activity during the general election of 2004.
} 
approximately $\$ 55,000$, the unemployment rate averaged three percent, the average precinct was $64 \%$ white, the average precinct was 7.5 miles from the proposed stadium location, and 61 percent of the population owned their house.

We use standard ordinary least squares regression methods to estimate the voting model in a cross-sectional framework. The results of several different specifications are reported in Table 5. Model 1 serves as a benchmark case; it does not include any of the variables concerning property values or property sales. The percentage of the population in another state in 1995 and income are both positively correlated with support for the stadium. The remaining variables are consistently insignificant.

Model 2 in Table 5 introduces the variables DOLLARANN1 and NOSALESI. The parameter estimates on the original set of variables do not change in magnitude and nor significance. The parameter on DOLLARANN1 is positive, but not statistically different from zero at the usual confidence levels, and the parameter on NOSALES1 is positive and statistically significant. The lack of significance of DOLLARANN1 is not surprising given that this information would have been obtained up to six months prior to the actual vote.

Model 3 includes only DOLLARANN2 and NOSALES2. The coefficient on DOLLARANN2 is positive and statistically significant. Precincts in which property values were increasing during the Announcement 2 period offered more support for the stadium. Specifically, there is a $1.2 \%$ increase (decrease) in support for the stadium for every $\$ 1000$ dollar increase (decrease) in house prices. Moreover, in precincts without any home sales during the Announcement 2 period, support for the stadium was approximately 7 percentage points greater. In this model, support for the stadium declined as the precinct was further from the proposed stadium site which might reflect lower expected benefits from amenities local to the stadium. 
Model 4 includes DOLLARANN1, NOSALES1, DOLLARANN2, and NOSALES2. In this model the variables associated with the first announcement period are insignificant whereas those associated with the second announcement period are significant. The evidence suggests that the impact of the stadium proposal on housing prices was more important (in a statistical and economic sense) during the second announcement period, closer to when the vote took place, than during the first announcement period, which occurred months ahead of the vote during the early part of the summer of 2004.

Models 5-7 repeat the estimation dropping the distance variable; there is some concern that the correlation between the distance from the proposed stadium site and the percentage of a precinct that are homeowners is sufficiently high to induce noise in the standard errors of the remaining parameter estimates. In Models 5-7 the results do not qualitatively change, however the percentage of the precinct's population that owned their own home is now negative and statistically significant. Combining the negative parameter estimates on home ownership with the positive parameter estimates on the average dollar effect of the first and second announcements and the positive parameter estimates on the dummy variables that indicate no house sales in a precinct suggests two things. First, property owners did not anticipate as high net benefits as non-property owners, perhaps because they feared a greater share of the tax burden or they considered themselves less mobile and therefore unable to leave the tax jurisdiction. Second, as houses sold for higher (reduced) prices in a particular precinct, support for the stadium proposal increased (fell). 


\section{Robustness Checks}

There might be concern that the results presented in Table 5 are driven by the level of turnout for the election rather than the impact of the announcements on property values. While the stadium proposal was coincident with the presidential election of 2004 , it is possible that turnout was the variable which responded to the signals provided by the residential property market. Therefore, we test whether the results reported in Table 5 are confirmed when voter turnout is the dependent variable rather than percentage voting in favor of the stadium proposal.

We obtained information on the number of registered voters for 94 of the 113 precincts in our sample. Knowing the total number of votes cast in each precinct facilitates calculating the percentage of registered voters who participated in the stadium vote. We re-estimated the models in Table 5 replacing percent support with percent turnout. The results are reported in Table 6.

Turnout was statistically higher in precincts with older populations, more wealthy populations and where there were more whites. A larger decline in house value is associated with larger turnout but these effects are never statistically significant. The only variables concerning property values significantly related to voter turnout are the dummy variables NOSALES1 and NOSALES2, which have negative parameter estimates. This suggests that turnout was higher when there was more information about the impact of the stadium proposal announcements on local property values. Even though the November 2004 election was a general election, information about home sales that would have an impact only on this referendum still had an impact on turnout. Combined with the results from Table 5, this is consistent with information about property value declines both increasing voter turnout and diminishing support for the stadium proposal, ceteris paribus. 
Another robustness check is to investigate whether the estimated price effects associated with announcements during the summer 2004 are spuriously related to the outcomes of previous votes in Arlington concerning tax increases for public projects. In several different special elections the citizens of Arlington failed to approve projects that would have increased local sales taxes but would have had limited or targeted public benefits. There is no reason to believe that the net benefits from these elections would be distributed similarly to those from the stadium referendum. These additional votes provide a convenient way to test whether the results from the 2004 stadium vote are merely correlated with some omitted variable measuring voter sentiments.

We obtained vote results for three specific public-good proposals in Arlington during the period immediately before the Cowboys stadium proposal and for the mayoral race preceding the stadium referendum. All three of the proposals we investigate here dealt with transportation issues. In May 2002 and February 2003 Arlington voters rejected proposed increases in the city’s sales tax to fund mass transit systems. ${ }^{15}$ In November 2003, Arlington supported a one-quarter cent increase in the local sales tax to fund a city-wide street maintenance program. We denote these as TransitTax1-TransitTax3. .

We also obtained vote totals for the May 2003 Arlington Mayoral election, which Robert Cluck won. Mayor Cluck spearheaded the initial negotiation with the Cowboys and was arguably instrumental in crafting the stadium proposal and securing sufficient public support for the proposal to pass. ${ }^{16}$ While the issues concerning the proposed stadium were not a part of the 2003 mayoral race, they may have been anticipated by voters. Therefore, it might be the case that those precincts which would be affected by a stadium proposal would show different support for Robert Cluck as mayoral candidate.

\footnotetext{
${ }_{15}^{15}$ As of June 2007, Arlington was the largest city in the United States without its own mass transit system.

${ }^{16}$ In May 2007, Robert Cluck won re-election as Mayor of Arlington, garnering 65\% of the votes cast (City of Arlington, City Secretary's Office, 2007).
} 
The data for these votes were gathered from 24 special polling locations, all of which are normal polling locations during general elections. Individual precinct data were unavailable, as a single polling location typically served multiple precincts, and matching data from a special election to precinct level data is somewhat difficult. We therefore relate the voting behavior for a particular special polling location with the precinct in which it is located. The descriptive statistics for these four additional elections are reported at the bottom of Table 4.

We re-estimate the models using percentage voting in support of the other proposals (Models 1-6) and the election of Mayor Robert Cluck (Models 7 and 8). Our expectation is that none of the variables describing the effect of stadium proposal announcements from 2004 would influence the support for tax proposals in 2002 or 2003 or the Mayoral race in 2003. In other words, we do not expect our estimated price effects to be statistically relevant to explaining the variance in voter support for pre-2004 proposals.

The results of these robustness checks are reported in Table 7a and Table 7b. In Table 7a we estimate two models for each of the alternative votes analyzed. The abbreviated model necessitated by fewer observations includes the majority of the demographic variables included in the previous models (the results were not altered by including all the variables), whereas the second model includes the estimated effects of Announcements 1 and 2 on Arlington property values.

In each case the vast majority of the parameter estimates are insignificant. However, those precincts with a large proportion of older residents tended to vote against TransitTax2 and in favor of electing Robert Cluck mayor of Arlington more so than in other precincts, ceteris paribus. None of the property-related variables are statistically significant, including the percentage of the precinct's population that was a homeowner. 
The small sample size calls into question the large number of parameters estimated in the full model of Tables 7a. The insignificant results may reflect true insignificance or weak power in the hypothesis tests because of the large number of degrees of freedom sacrificed. These models were therefore re-estimated after reducing the number of parameters to be estimated, specifically including only the estimated dollar effects of the stadium announcements. Again, our priors are that there should be no significant relationship between the price effects and the pre2004 vote results. Results are reported in Table 7b.

Only one price effect is statistically significant; that being for TransitTaxl. Given that this is the only parameter out of 24 estimated parameters concerning property values in Table $7 \mathrm{a}$ and Table $7 \mathrm{~b}$, this significant parameter is within the bounds of convention and likely reflects a Type I error.

Overall, the models presented in Table 6 and Table 7 support the conclusion that our primary results reported in Table 5 are not spurious or that the results supporting the homevoter hypothesis are being caused by some unmeasured influence on voter behavior. Given the direct test of the homevoter hypothesis undertaken here, we find support for the hypothesis despite the fact that the stadium proposal passed.

\section{Discussion and Conclusions}

This paper adds to and expands on a relatively small but growing empirical literature investigating the homevoter hypothesis. First, we incorporate capitalized house price effects from an uncertain future public good project in explaining local support for the public good project. Second, we are able to identify specific events that arguably increased the likelihood that public good project would be undertaken, and can therefore test whether price effects under 
reduced uncertainty are more important in explaining voting outcomes. Finally, given the specific location of the public good project we investigate, wealth and consumption effects can both vary with distance from the proposed public project's location and we therefore incorporate spatial relationships in the analysis.

This is the first paper investigating a large discrete public good project in the context of the homevoter hypothesis and also seems to be the first to provide a direct test of the hypothesis. Our empirical approach entails identifying specific events which increased the probability that a large public good project would be undertaken (with a subsequent increase in local sales and use taxes), and estimating the impact of these events on local residential property values. We then combine the estimated price effects and local demographics to explain precinct-level support for the public good project. Increases in house prices associated with an increasing probability that the public project will be undertaken are used as (noisy) signals that the market anticipates the project to offer a positive net marginal benefit. The homevoter hypothesis posits that positive (negative) noisy signals should correspond to increased (decreased) support for the proposed public-good project.

We apply this methodology to the November 2004 referendum to build a stadium for the NFL's Dallas Cowboys in Arlington, Texas. At the time, voters in Arlington approved an increase in local sales and user taxes to contribute up to $\$ 325$ million to the construction costs of a new stadium. In the months before the election, two distinct events occurred that arguably increased the probability that the stadium proposal would be accepted: the announcement that the mayor was in discussion with the team concerning a new stadium and the announcement that the city council had approved a city-wide referendum concerning the stadium proposal. We accommodate temporal and spatial variation in the effect of the potential stadium project by 
allowing the impact of these two announcements to vary with distance from the proposed stadium site. We find that support for the stadium fell (increased) where property values fell (rose) after these two announcements, ceteris paribus. We also find that homeowners in general were less likely to support the stadium proposal.

However, if average property values in Arlington fell during the months leading up to the stadium referendum, consistent with Dehring Depken and Ward [26], the referendum's success would seem in violation of the homevoter hypothesis. One explanation is differences between the average homeowner and the median voter. The median voter might vote in the affirmative if other determinants rather than expected changes in property values are considered. For example, individuals who anticipated considerable personal consumption benefits from a new stadium, e.g., because they anticipated attending events in the new stadium, might have been more likely to turn out and to vote 'yes.' Further, those who anticipated considerably smaller costs from building the stadium, e.g., transient or more mobile residents, might have been more likely to vote in the affirmative, everything else equal. Finally, a relatively small net cost may not induce an abstainer to turn out and vote 'no,' and therefore the median voter might have differed considerably from the average homeowner in Arlington.

Another explanation could be imperfect information in voting markets. Public officials may personally benefit from a project even if there are negative net benefits for the city as a whole and might therefore focus on the perceived or anticipated benefits of the stadium while deemphasizing the costs involved. Indeed, Porter and Thomas [29] point out that city and team officials often over-promote the anticipated public benefits of a proposed stadium project, including appeals to city pride and notoriety, increased economic activity from tourism, and the potential for hosting mega-events such as a Super Bowl or an NCAA Final Four. 
These public benefits have proven difficult to measure and identify; most academic studies suggest the public benefits after a stadium is built are considerably less than those predicted before a stadium is built. However, to the extent that voters do not completely dismiss these claims as mere 'cheap talk,' such claims might influence the median voter's support for a stadium subsidy. Our results suggest that voters more susceptible to 'cheap talk,' and those with less experience with past similar projects, were more likely to support the stadium proposal.

A related explanation also stems from imperfect information in voting markets. Voters with shorter time horizons and therefore less direct exposure to potential future tax increases are more likely to estimate larger personal benefits and smaller personal costs of a large discrete project such as stadium. These voters may support the proposal even without positive net benefits. Our results are also consistent with this explanation.

While reduced-form in nature, the homevoter hypothesis provides an intuitively appealing explanation for how (and why) homeowners vote on public-good proposals. When a large, discrete project funded with a considerable outlay of public money is debated, the outcome of a public referendum often hinges upon the public's perception of the costs and benefits of the project. Our empirical results concerning the 2004 stadium referendum in Arlington, Texas, suggest that on the margin voters internalized market information concerning the expected net benefits of the stadium conveyed through changing property values associated with an increased likelihood that the stadium would be built.

Consistent with the homevoter hypothesis, regardless of whether property values changed in a voting precinct during the stadium debate, those precincts with a greater proportion of homeowners showed less support for the stadium proposal. Moreover, providing more direct support for the homevoter hypothesis, in precincts where property values fell during the 
Arlington stadium debate there was an additional reduction in support for the proposal. This suggests that price changes associated with the stadium debate were conveyed in some fashion and altered the expected net benefits of the stadium. Future research in the context of stadium referenda and the homevoter hypothesis would add to our empirical understanding of how homeowners support proposed large, discrete, public good projects. 


\section{References}

[1] W. Oates, The effects of property taxes and local public spending on property values: An empirical study of tax capitalization and the Tiebout hypothesis, Journal of Political Economy 77 (1969) 957-971.

[2] D Wildasin, Local public goods, property values, and local public choice, Journal of Urban Economics 6 (1979) 521-534.

[3] J. C. Sonstelie and P. R. Portney, Take the money and run. A theory of voting in local referenda, Journal of Urban Economics 8 (1980) 187-195.

[4] J. K. Brueckner and M.S. Joo, Voting with capitalization, Regional Science and Urban Economics 21 (1991) 453-467.

[5] W. A. Fischel, The homevoter hypothesis. Harvard University Press, Cambridge, MA, 2001.

[6] E. Brunner, J. Sonstelie, and M. Thayer. Capitalization and the voucher: an analysis of precinct returns from California's Proposition 174, Journal of Urban Economics 50 (2001) 517536.

[7] E. Brunner and J. Sonstelie, Homeowners, property values, and the political economy of the school voucher, Journal of Urban Economics 54 (2003) 239-257.

[8] G. Carlino and N. E. Coulson, Compensating differentials and the social benefits of the NFL, Journal of Urban Economics 56 (2004) 25-50.

[9] G. Carlino and N. E. Coulson, Compensating differentials and the social benefits of the NFL: A Reply, Journal of Urban Economics 60 (2006) 132-138.

[10] C. Tu, How does a new sports stadium affect housing values, Land Economics 81 (2005) 379-395.

[11] D. Coates, B. R. Humphreys, and A. Zimbalist, Compensating differentials and the social benefits of the NFL: A Comment, Journal of Urban Economics 60 (2006) 124-131.

[12] H.S. Campbell, Professional Sports and Urban Development: A Brief Review of Issues and Studies, Review of Regional Studies, 29 (1999) 272-92.

[13] A.C. Nelson, Prosperity or Blight? A Question of Major League Stadia Locations, Economic Development Quarterly, 15 (2001) 255-65.

[14] R.A. Baade and R. F. Dye, The Impact of Stadiums and Professional Sports on Metropolitan Area Development, Growth and Change, 21 (1990) pp. 1-14. 
[15] D. Coates and B. R. Humphreys, The Effect of Professional Sports on Earnings and Employment in the Services and Retail Sectors in US Cities, Regional Science and Urban Economics, 33 (2003) 175-98.

[16] M. Lavoie and G. Rodriguez, The Economic Impact of Professional Teams on Monthly Hotel Occupancy Rates of Canadian Cities: A Box-Jenkins Approach, Journal of Sports Economics, 6 (2005) 314-24.

[17] D. Coates, The Tax Benefits of Hosting the Super Bowl and the MLB All-Star Game: The Houston Experience, International Journal of Sport Finance, 1 (2006) 239-252.

[18] D. Coates and C.A. Depken, Mega-Events: Is the Texas-Baylor game to Waco what the Super Bowl is to Houston? mimeo, Department of Economics, The University of Texas Arlington.

[19] C.M. Clapp and J. Hakes, How Long a Honeymoon? The Effect of New Stadiums on Attendance in Major League Baseball, Journal of Sports Economics, 6 (2005) 237-63.

[20] K.G. Quinn, Bursik, P.B., Borick, C.P., and Raethz, L., Do New Digs Mean More Wins? The Relationship between a New Venue and a Professional Sports Team's Competitive Success, Journal of Sports Economics, 4 (2003) 167-82.

[21] C.A. Depken, The Impact of New Stadiums on Professional Baseball Team Finances, Public Finance and Management, 6 (2006) 436-74.

[22] J. Siegfried and A. Zimbalist, The Economics of Sports Facilities and Their Communities, Journal of Economic Perspectives, 14 (2000) 95-114.

[23] S.J. Agostini, J.M. Quigley, E. Smolensky, Stickball in San Francisco, in: R.G. Noll, A. Zimbalist (Eds.), Sports, Jobs and Taxes: The Economic Impact of Sports Teams and Stadiums, The Brookings Institution Press, Washington, DC, 1997, 385-426.

[24] C.A. Depken, Fan Loyalty and Stadium Funding in Professional Baseball," Journal of Sports Economics, 1 (2000) 124-138.

[25] D. Coates and B. R. Humphreys, Proximity benefits and voting on stadium and arena subsidies, Journal of Urban Economics 59 (2006) 285-299.

[26] C. A. Dehring, C. A. Depken, and M. R. Ward, The impact of stadium announcements on residential property values: evidence from a natural experiment in Dallas-Fort Worth," mimeo, Department of Economics, University of Texas - Arlington.

[27] C.A. Depken, Fan Loyalty in Professional Sports: An Extension to the National Football League, Journal of Sports Economics, 2 (2001) 275-284. 
[28] P. K. Porter and C. R. Thomas, The role of subsidies in the location and pricing of sports, unpublished manuscript (2006) Department of Economics, University of South Florida. 
Table 1: Major Announcements Concerning Dallas Cowboys Stadium Site Search

\begin{tabular}{|c|c|c|}
\hline & Date & Description \\
\hline Announcement $1 *$ & July 17,2004 & $\begin{array}{l}\text { Arlington's mayor announces he has been in secret } \\
\text { negotiations with the team about building a new publicly } \\
\text { subsidized stadium near the existing baseball stadium in } \\
\text { Arlington. }\end{array}$ \\
\hline Announcement $2 *$ & August 17, 2004 & $\begin{array}{l}\text { Arlington's city council approves a stadium ballot } \\
\text { initiative for the November } 2004 \text { general election. The } \\
\text { ballot initiative asks voters to approve up to } \$ 325 \text { million } \\
\text { towards land acquisition and construction costs for a new } \\
\text { stadium located near the existing baseball stadium in } \\
\text { Arlington. The ballot initiative also includes a one half } \\
\text { cent sales tax in Arlington as well as additional hotel and } \\
\text { car rental taxes. }\end{array}$ \\
\hline Announcement 3 & November 3, 2004 & $\begin{array}{l}\text { Arlington voters approve ballot initiative on November } 3 \text {, } \\
2004 \text {, and the additional taxes are instituted on April } 1 \text {, } \\
2005 \text {. }\end{array}$ \\
\hline
\end{tabular}


Table 2: Descriptive Statistics of Arlington House Sales

\begin{tabular}{|c|c|c|c|c|c|}
\hline Variable & Description & Mean & Std. Dev. & Min & Max \\
\hline PRICE & Sales price & 132,437 & 63,133 & 23,800 & 900,000 \\
\hline SQFT & Square footage & 1943 & 675 & 670 & 5596 \\
\hline BATHS & Number of bathrooms & 2.26 & .67 & 1 & 6 \\
\hline AGE & House age (years) & 22.69 & 15.68 & 0 & 77 \\
\hline ACRES & Lot size in acres & .215 & .142 & .138 & 3.07 \\
\hline POOL & Pool on property (1=Yes) & .14 & .35 & 0 & 1 \\
\hline PARK & Number of covered parking spaces & 1.78 & .66 & 0 & 6 \\
\hline STORIES & Number of stories & 1.21 & .43 & 0 & 3 \\
\hline OCCUPO & Owner occupied (1=Yes) & .45 & .50 & 0 & 1 \\
\hline OCCUPV & Vacant (1=Yes) & .37 & .48 & 0 & 1 \\
\hline TAKSEA & $\begin{array}{l}\text { Percentage of third grade students that } \\
\text { scored acceptable on Texas Assessment of } \\
\text { Knowledge Skills test }\end{array}$ & 70.78 & 14.34 & 23 & 94 \\
\hline TAKSEC & $\begin{array}{l}\text { Percentage of third grade students that } \\
\text { scored commendable on Texas Assessment } \\
\text { of Knowledge Skills test }\end{array}$ & 14.89 & 7.49 & 1 & 30 \\
\hline 12-DSTAD & $\begin{array}{l}12 \text { - Distance from the proposed stadium } \\
\text { site in Arlington in miles }\end{array}$ & 8.08 & 2.62 & 2.08 & 12.44 \\
\hline DISTFTWORTH & $\begin{array}{l}\text { Distance from Anon Carter Stadium at } \\
\text { Texas Christian University (Fort Worth } \\
\text { CBD) }\end{array}$ & 14.18 & 2.36 & 8.43 & 18.26 \\
\hline
\end{tabular}


Table 3: Housing Price Regression Results

\begin{tabular}{|c|c|c|c|}
\hline Variable & Parameter Estimate & Variable & Parameter Estimate \\
\hline \multirow[t]{2}{*}{ AGE } & $-0.012 * * *$ & (1-DSTAD) & $-0.157 *$ \\
\hline & $(0.001)$ & & $(0.086)$ \\
\hline \multirow[t]{2}{*}{ AGE2 } & $6.5 \mathrm{e}-05 * * *$ & (1-DSTAD)xANN1 & 0.223 \\
\hline & $(0.000)$ & & $(0.199)$ \\
\hline \multirow[t]{2}{*}{ SQFT } & $2.969 \mathrm{e}-04 * * *$ & (1-DSTAD)xANN2 & -0.290 \\
\hline & $(0.000)$ & & $(0.218)$ \\
\hline \multirow[t]{2}{*}{ LNACRES } & $0.156 * * *$ & (1-DSTAD)xANN3 & $-0.542^{* *}$ \\
\hline & $(0.013)$ & & $(0.245)$ \\
\hline \multirow[t]{2}{*}{ POOL } & $0.093 * * *$ & (2-DSTAD) & $-0.092 *$ \\
\hline & $(0.010)$ & & $(0.052)$ \\
\hline \multirow[t]{2}{*}{ BATHS } & $0.056 * * *$ & (2-DSTAD)xANN1 & -0.096 \\
\hline & $(0.009)$ & & $(0.109)$ \\
\hline \multirow[t]{2}{*}{ PARK } & $0.028 * * *$ & (2-DSTAD)xANN2 & 0.169 \\
\hline & $(0.006)$ & & $(0.119)$ \\
\hline \multirow[t]{2}{*}{ STORIES } & $-0.059 * * *$ & (2-DSTAD)xANN3 & -0.028 \\
\hline & $(0.010)$ & & $(0.122)$ \\
\hline \multirow[t]{2}{*}{ OCCUPO } & $0.057 * * *$ & (3-DSTAD) & 0.003 \\
\hline & $(0.009)$ & & $(0.033)$ \\
\hline \multirow[t]{2}{*}{ OCCUPV } & $-0.034 * * *$ & (3-DSTAD)xANN1 & 0.027 \\
\hline & $(0.010)$ & & $(0.048)$ \\
\hline \multirow[t]{2}{*}{ TAKSEA } & $-0.001 * * *$ & (3-DSTAD)xANN2 & $-0.089 *$ \\
\hline & $(0.000)$ & & $(0.053)$ \\
\hline \multirow[t]{2}{*}{ TAKSEC } & $0.006^{* * *}$ & (3-DSTAD)xANN3 & $0.099 *$ \\
\hline & $(0.001)$ & & $(0.054)$ \\
\hline \multirow[t]{2}{*}{ DISTFW } & $-0.012 * * *$ & Constant & $11.474 * * *$ \\
\hline & $(0.004)$ & & $(0.093)$ \\
\hline \multirow[t]{2}{*}{ 12-DSTAD } & $0.022 * * *$ & & \\
\hline & $(0.007)$ & & \\
\hline \multirow[t]{2}{*}{ (12-DSTAD)xANN1 } & 0.000 & & \\
\hline & $(0.000)$ & & \\
\hline \multirow[t]{2}{*}{ (12-DSTAD)xANN2 } & 0.004 & Observations & 2,241 \\
\hline & $(0.003)$ & R-squared & 0.85 \\
\hline \multirow[t]{2}{*}{ (12-DSTAD)xANN3 } & 0.002 & F-statistic & $186.31 * * *$ \\
\hline & $(0.005)$ & $\mathrm{H}_{0}$ : Fixed Effects Equal & $13.724 * * *$ \\
\hline \multicolumn{4}{|c|}{$\begin{array}{l}\text { Notes: Dependent variable is the natural logarithm of house price. Month dummy variables are not shown. A } \\
\text { GLS estimator is employed that allows for heteroskedasticity by zipcode. Variables defined in Tables } 1 \text { and } 2 . \\
\text { Standard errors in parentheses. } * * * \mathrm{p}<0.01, * * \mathrm{p}<0.05, * \mathrm{p}<0.1\end{array}$} \\
\hline
\end{tabular}


Table 4: Descriptive Statistics of Arlington Voting Precincts

\begin{tabular}{|c|c|c|c|c|c|}
\hline Variable & Description & Mean & Std. Dev. & Min & $\operatorname{Max}$ \\
\hline PCTYES & Percent voting 'YES' on the stadium proposal & 56.71 & 8.93 & 43.37 & 100.00 \\
\hline TURNOUT $^{\mathrm{a}}$ & Percent of registered voters who voted on Cowboys stadium proposal & 61.67 & 14.40 & 0.00 & 83.00 \\
\hline PCTINOTHST95 & Percent living in a different state in 1995 & 10.28 & 5.44 & 1.10 & 23.60 \\
\hline PCTOVER65 & Percent over 65 & 6.74 & 4.55 & 1.50 & 23.90 \\
\hline INCOME & Median household income (in thousands) & 54.56 & 18.39 & 19.30 & 104.69 \\
\hline UNEMPLOYMENT & Unemployment rate & 3.05 & 1.37 & 0.60 & 6.20 \\
\hline PCTWHITE & Percent white & 63.85 & 18.91 & 9.00 & 90.00 \\
\hline PCTOWNHOME & Percent Homeowners & 61.17 & 28.84 & 4.10 & 95.70 \\
\hline DOLLARANN1 & Average price effect after Announcement 1 (thousands) & 0.71 & 1.07 & -3.60 & 4.64 \\
\hline NOSALES1 & No properties sold between Announcement 1 and Announcement 2 & 0.34 & 0.47 & 0 & 1 \\
\hline DOLLARANN2 & Average price effect after Announcement 2 (thousands) & 0.66 & 1.97 & -4.27 & 8.78 \\
\hline NOSALES2 & No properties sold between Announcement 2 and Announcement 3 & 0.22 & 0.41 & 0 & 1 \\
\hline TransitTax $1^{\mathrm{b}}$ & May 2002 proposal for mass transit & 43.28 & 5.72 & 32.08 & 59.64 \\
\hline TransitTax $2^{b}$ & Feb 2003 proposal for mass transit and street maintenance & 42.26 & 7.52 & 29.20 & 60.83 \\
\hline TransitTax $^{\mathrm{b}}$ & Nov 2003 proposal for street maintenance & 77.36 & 5.34 & 66.22 & 86.61 \\
\hline Mayor $^{\mathrm{b}}$ & Nov 2002 Mayoral election of Robert Cluck & 53.27 & 7.52 & 41.26 & 68.94 \\
\hline Observations & 113 & & & & \\
\hline
\end{tabular}


Table 5: Support for the Cowboys Stadium Proposal (Dependent variable: Percent Voting Yes)

\begin{tabular}{|c|c|c|c|c|c|c|c|}
\hline & (1) & (2) & (3) & (4) & (5) & (6) & (7) \\
\hline COEFFICIENT & PERYES & PERYES & PERYES & PERYES & PERYES & PERYES & PERYES \\
\hline \multirow[t]{2}{*}{ PCTINOTHSTATE } & $0.483 * *$ & $0.417 *$ & $0.429 *$ & $0.415^{*}$ & $0.442 *$ & $0.436^{*}$ & $0.431 *$ \\
\hline & $(0.24)$ & $(0.24)$ & $(0.22)$ & $(0.22)$ & $(0.24)$ & $(0.23)$ & $(0.23)$ \\
\hline \multirow[t]{2}{*}{ PCTOVER65 } & -0.0979 & -0.123 & 0.0492 & -0.0217 & 0.0718 & 0.238 & 0.208 \\
\hline & $(0.28)$ & $(0.29)$ & $(0.27)$ & $(0.28)$ & $(0.26)$ & $(0.26)$ & $(0.27)$ \\
\hline \multirow[t]{2}{*}{ INCOME } & $0.155^{*}$ & $0.181 * *$ & $0.148^{*}$ & $0.157 * *$ & $0.188 * *$ & $0.174 * *$ & $0.179 * *$ \\
\hline & $(0.081)$ & $(0.081)$ & $(0.077)$ & $(0.078)$ & $(0.082)$ & $(0.077)$ & $(0.080)$ \\
\hline \multirow[t]{2}{*}{ UNEMP } & 0.111 & 0.231 & -0.404 & -0.254 & 0.242 & -0.253 & -0.186 \\
\hline & $(0.78)$ & $(0.81)$ & $(0.73)$ & $(0.77)$ & $(0.81)$ & $(0.75)$ & $(0.79)$ \\
\hline \multirow[t]{2}{*}{ PCTWHITE } & -0.00200 & -0.0184 & -0.0457 & -0.0364 & -0.0524 & -0.0897 & -0.0862 \\
\hline & $(0.073)$ & $(0.075)$ & $(0.070)$ & $(0.071)$ & $(0.072)$ & $(0.069)$ & $(0.070)$ \\
\hline \multirow[t]{2}{*}{ DIST } & -0.361 & -0.437 & $-0.623^{* *}$ & $-0.670^{* *}$ & & & \\
\hline & $(0.27)$ & $(0.28)$ & $(0.27)$ & $(0.28)$ & & & \\
\hline \multirow[t]{2}{*}{ PCTOWNHOUSE } & -0.0588 & -0.0377 & -0.0410 & -0.0445 & $-0.0821 *$ & $-0.0981 * *$ & $-0.104 * *$ \\
\hline & $(0.056)$ & $(0.056)$ & $(0.052)$ & $(0.053)$ & $(0.049)$ & $(0.047)$ & $(0.048)$ \\
\hline \multirow{2}{*}{ NOSALES1 } & & $4.690 * *$ & & -1.243 & $4.408 * *$ & & -1.273 \\
\hline & & $(2.05)$ & & $(2.61)$ & $(2.06)$ & & $(2.67)$ \\
\hline \multirow[t]{2}{*}{ DOLLARANN1 } & & 1.143 & & 0.627 & 0.767 & & 0.277 \\
\hline & & $(0.89)$ & & $(0.87)$ & $(0.87)$ & & $(0.88)$ \\
\hline \multirow[t]{2}{*}{ NOSALES2 } & & & $7.150 * * *$ & $8.553 * * *$ & & $7.056 * * *$ & $8.229 * * *$ \\
\hline & & & $(1.90)$ & $(2.67)$ & & $(1.94)$ & $(2.73)$ \\
\hline \multirow[t]{2}{*}{ DOLLARANN2 } & & & $1.225 * *$ & $1.162 * *$ & & $0.793 *$ & 0.755 \\
\hline & & & $(0.49)$ & $(0.50)$ & & $(0.46)$ & $(0.48)$ \\
\hline \multirow[t]{2}{*}{ Constant } & $50.05 * * *$ & $47.06^{* * * *}$ & $52.86^{* * * *}$ & $52.21 * * *$ & $47.01 * * *$ & $51.52 * * *$ & $51.47 * * *$ \\
\hline & $(7.03)$ & $(7.19)$ & $(6.55)$ & $(6.93)$ & $(7.24)$ & $(6.65)$ & $(7.08)$ \\
\hline Observations & 113 & 113 & 113 & 113 & 113 & 113 & 113 \\
\hline R-squared & 0.21 & 0.25 & 0.34 & 0.34 & 0.23 & 0.30 & 0.31 \\
\hline
\end{tabular}


Table 6: Voter Turnout as a Robustness Check

\begin{tabular}{|c|c|c|c|c|}
\hline & (1) & (2) & (3) & (4) \\
\hline COEFFICIENT & TURNOUT & TURNOUT & TURNOUT & TURNOUT \\
\hline \multirow[t]{2}{*}{ PCTINOTHSTATE } & 0.0236 & 0.0691 & 0.102 & 0.0967 \\
\hline & $(0.31)$ & $(0.30)$ & $(0.28)$ & $(0.29)$ \\
\hline \multirow[t]{2}{*}{ PCTOVER65 } & $0.594 *$ & 0.485 & 0.334 & 0.316 \\
\hline & $(0.31)$ & $(0.31)$ & $(0.30)$ & $(0.31)$ \\
\hline \multirow[t]{2}{*}{ INCOME } & $0.401 * * *$ & $0.381 * * *$ & $0.387 * * *$ & $0.390 * * *$ \\
\hline & $(0.096)$ & $(0.094)$ & $(0.087)$ & $(0.090)$ \\
\hline \multirow[t]{2}{*}{ UNEMP } & -0.172 & -0.208 & 0.199 & 0.221 \\
\hline & $(0.99)$ & $(1.00)$ & $(0.91)$ & $(0.96)$ \\
\hline \multirow[t]{2}{*}{ PCTWHITE } & $0.159 *$ & $0.185 * *$ & $0.211 * * *$ & $0.212 * * *$ \\
\hline & $(0.085)$ & $(0.083)$ & $(0.078)$ & $(0.079)$ \\
\hline \multirow[t]{2}{*}{ PCTOWNHOUSE } & 0.0384 & 0.00105 & 0.0364 & 0.0338 \\
\hline & $(0.061)$ & $(0.060)$ & $(0.056)$ & $(0.059)$ \\
\hline \multirow[t]{2}{*}{ NOSALES1 } & & $-6.781 * * *$ & & -0.378 \\
\hline & & $(2.56)$ & & $(3.01)$ \\
\hline \multirow[t]{2}{*}{ DOLLARANN1 } & & -0.344 & & 0.150 \\
\hline & & $(1.02)$ & & $(0.99)$ \\
\hline \multirow[t]{2}{*}{ NOSALES2 } & & & $-11.60 * * *$ & $-11.23 * * *$ \\
\hline & & & $(2.54)$ & $(3.27)$ \\
\hline \multirow[t]{2}{*}{ DOLLARANN2 } & & & -0.814 & -0.837 \\
\hline & & & $(0.60)$ & $(0.63)$ \\
\hline \multirow[t]{2}{*}{ Constant } & $23.09 * *$ & $27.55 * * *$ & $22.91 * *$ & $22.94 * *$ \\
\hline & $(9.67)$ & $(9.78)$ & $(8.77)$ & $(9.33)$ \\
\hline Observations & 93 & 93 & 93 & 93 \\
\hline R-squared & 0.62 & 0.65 & 0.70 & 0.70 \\
\hline \multicolumn{5}{|c|}{$\begin{array}{l}\text { Notes: Dependent variable is the percent of eligible voters who participated in the } \\
\text { Cowboys stadium referendum. Variables as defined in Table } 4 \text {. Standard errors in } \\
\text { parentheses. } * * * p<0.01, * * \mathrm{p}<0.05, * \mathrm{p}<0.1\end{array}$} \\
\hline
\end{tabular}


Table 7a: Previous Special Elections in Arlington as a Robustness Check

\begin{tabular}{|c|c|c|c|c|c|c|c|c|}
\hline & $(1)$ & $(2)$ & (3) & (4) & (5) & (6) & $(7)$ & $(8)$ \\
\hline COEFFICIENT & TransitTax 1 & TransitTax 1 & TransitTax2 & TransitTax2 & TransitTax3 & TransitTax3 & Mayor & Mayor \\
\hline \multirow[t]{2}{*}{ PCTOVER65 } & -0.236 & -0.481 & $-0.646^{*}$ & $-1.002 * *$ & 0.360 & 0.473 & $1.012 * * *$ & $0.950 * *$ \\
\hline & $(0.25)$ & $(0.29)$ & $(0.33)$ & $(0.39)$ & $(0.23)$ & $(0.29)$ & $(0.28)$ & $(0.34)$ \\
\hline \multirow[t]{2}{*}{ INCOME } & -0.0731 & 0.0537 & -0.0959 & -0.00626 & 0.161 & -0.0372 & 0.197 & 0.0963 \\
\hline & $(0.12)$ & $(0.18)$ & $(0.15)$ & $(0.24)$ & $(0.11)$ & $(0.18)$ & $(0.13)$ & $(0.21)$ \\
\hline \multirow[t]{2}{*}{ PCTOWNHOME } & -0.0207 & -0.0256 & 0.0678 & 0.106 & -0.0956 & -0.0748 & -0.110 & -0.0788 \\
\hline & $(0.067)$ & $(0.074)$ & $(0.087)$ & $(0.10)$ & $(0.062)$ & $(0.073)$ & $(0.073)$ & $(0.087)$ \\
\hline \multirow[t]{2}{*}{ NOSALES1 } & & -1.512 & & 4.572 & & 0.278 & & 0.574 \\
\hline & & $(4.91)$ & & $(6.66)$ & & $(4.87)$ & & $(5.77)$ \\
\hline \multirow[t]{2}{*}{ DOLLARANN1 } & & 1.257 & & 2.913 & & 1.645 & & 2.364 \\
\hline & & $(2.28)$ & & $(3.09)$ & & $(2.26)$ & & $(2.68)$ \\
\hline \multirow[t]{2}{*}{ NOSALES2 } & & -2.739 & & -5.427 & & 7.057 & & 5.390 \\
\hline & & $(5.79)$ & & $(7.86)$ & & $(5.75)$ & & $(6.81)$ \\
\hline \multirow[t]{2}{*}{ DOLLARANN2 } & & -1.689 & & -2.253 & & 1.615 & & -0.127 \\
\hline & & $(1.33)$ & & $(1.81)$ & & $(1.32)$ & & $(1.57)$ \\
\hline \multirow[t]{2}{*}{ Constant } & $50.04 * * *$ & $46.94 * * *$ & $47.84 * * *$ & $42.25 * * *$ & $72.05 * * *$ & $75.96 * * *$ & $42.33 * * *$ & $42.63 * * *$ \\
\hline & $(4.64)$ & $(5.71)$ & $(6.02)$ & $(7.76)$ & $(4.30)$ & $(5.67)$ & $(5.08)$ & $(6.71)$ \\
\hline Observations & 24 & 24 & 24 & 24 & 24 & 24 & 24 & 24 \\
\hline R-squared & 0.14 & 0.35 & 0.16 & 0.30 & 0.16 & 0.26 & 0.41 & 0.48 \\
\hline
\end{tabular}

Table 7b: Previous Special Elections in Arlington as a Robustness Check

\begin{tabular}{|c|c|c|c|c|c|c|c|c|}
\hline & $(1)$ & (2) & (3) & (4) & (5) & $(6)$ & (7) & $(8)$ \\
\hline COEFFICIENT & TransitTax 1 & TransitTax 1 & TransitTax 2 & TransitTax 2 & TransitTax3 & TransitTax3 & Mayor & Mayor \\
\hline \multirow[t]{2}{*}{ PCTOVER65 } & -0.236 & $-0.469 *$ & $-0.646^{*}$ & $-0.887 * *$ & 0.360 & 0.398 & $1.012 * * *$ & $0.898 * * *$ \\
\hline & $(0.25)$ & $(0.26)$ & $(0.33)$ & $(0.35)$ & $(0.23)$ & $(0.27)$ & $(0.28)$ & $(0.31)$ \\
\hline \multirow[t]{2}{*}{ INCOME } & -0.0731 & -0.0493 & -0.0959 & -0.0492 & 0.161 & 0.151 & 0.197 & 0.248 \\
\hline & $(0.12)$ & $(0.12)$ & $(0.15)$ & $(0.16)$ & $(0.11)$ & $(0.13)$ & $(0.13)$ & $(0.14)$ \\
\hline \multirow[t]{2}{*}{ PCTOWNHOME } & -0.0207 & -0.00504 & 0.0678 & 0.0855 & -0.0956 & -0.0985 & -0.110 & -0.0999 \\
\hline & $(0.067)$ & $(0.063)$ & $(0.087)$ & $(0.086)$ & $(0.062)$ & $(0.066)$ & $(0.073)$ & $(0.075)$ \\
\hline \multirow[t]{2}{*}{ DOLLARANN1 } & & $2.631 *$ & & 2.391 & & -0.345 & & 0.689 \\
\hline & & $(1.33)$ & & $(1.80)$ & & $(1.38)$ & & $(1.58)$ \\
\hline \multirow[t]{2}{*}{ DOLLARANN2 } & & -1.091 & & -1.486 & & 0.273 & & -1.172 \\
\hline & & $(0.88)$ & & $(1.19)$ & & $(0.91)$ & & $(1.05)$ \\
\hline \multirow[t]{2}{*}{ Constant } & $50.04 * * *$ & $48.18 * * *$ & $47.84 * * *$ & $45.15 * * *$ & $72.05 * * *$ & $72.56^{* * *}$ & $42.33 * * *$ & $40.05 * * *$ \\
\hline & $(4.64)$ & $(4.69)$ & $(6.02)$ & $(6.36)$ & $(4.30)$ & $(4.87)$ & $(5.08)$ & $(5.57)$ \\
\hline Observations & 24 & 24 & 24 & 24 & 24 & 24 & 24 & 24 \\
\hline R-squared & 0.14 & 0.32 & 0.16 & 0.28 & 0.16 & 0.16 & 0.41 & 0.45 \\
\hline
\end{tabular}




\section{Figure 1}

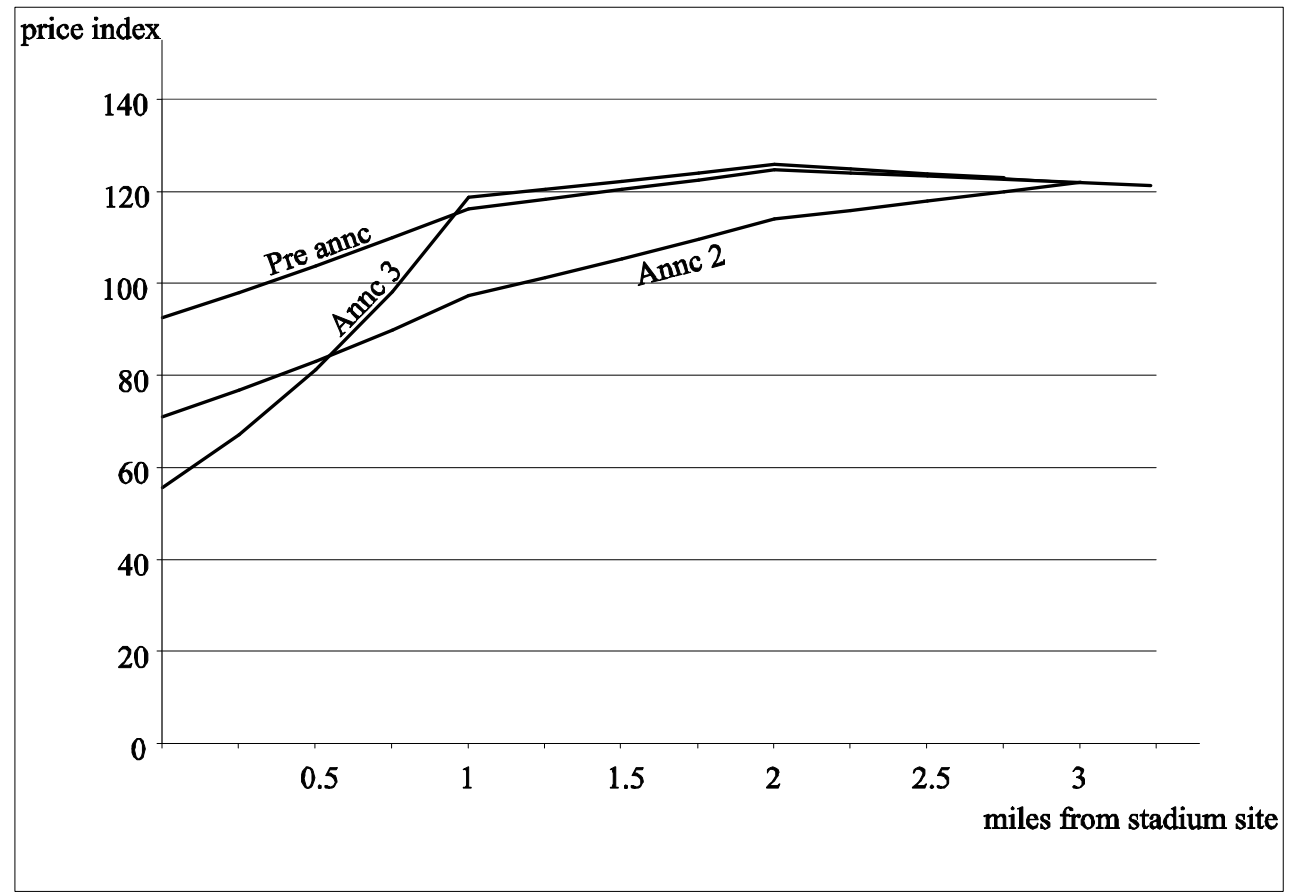

The intra city-analysis reveals that the proposed stadium was in a localized value crater. There are no significant house price effects from announcement 1 . Following announcement 2 , house prices decrease by $8.5 \%$ per mile with each mile closer to the stadium for houses within three miles of the stadium. Following the stadium vote, denoted Announcement 3, this price effect reverses between 1 and 3 miles from the stadium. However, with within 1 mile of the stadium, house prices again decrease with proximity to the stadium. Over the sample period, there is a $37 \%$ decrease in price for those properties on the edge of the stadium. 